\title{
HOW CAN WE SPREAD THE QUALITY VIRUS IN DOMESTIC ORGANIZATIONS?
}

\author{
K. Szabó \\ Budapest University of Technology and Economics, Müegyetem rkp. 3, 1111, Budapest, Hungary, \\ e-mail: krisztian.szabo@claas.com
}

\begin{abstract}
There is no room for debate about that the quality is one of the most important competitive factor and nobody against that this quality virus has to be spread. The paper would like to help with methods and techniques -what are not well known and used in the domestic organizations- to spread this virus in different fields of the organization. Its strategic motto is: Instead of quality management development and improvement the quality of the management has to be developed in the interest of quality management.

Today, that idea has to be given up what says more and more modern quality systems development start is needed instead of it the whole quality of the management has to be developed. High level of the quality system is not equal with the high quality of the management. It has to be turned. The high level of the management quality will ensure the possibility of well operating high level quality management. The paper wants to present this from different aspects on the one hand by comparing the classical development of quality management systems on the other hand by new (volume, profit and quality) approaches of certain management elements and methods.
\end{abstract}

Keywords: quality virus, quality conscious management, Seghezzi palace, management and quality management connections, new audit approaches, domestic quality model.

\section{PERIODS OF THE QUALITY VIRUS FROM QUALITY CONTROLL TILL INTEGRATED MANAGEMENT SYSTEMS}

\subsection{First period: QC}

Main characteristic of the first step is the quality check (QC). The small quality virus (black point on the Fig. 1) started to infect the quantity and profit oriented production systems with the philosophy of quality. The first phase was characterized by strong finished product control. The paradox from management point of view is that the Quality Department is responsible for the quality but they have no active effect on production. They are responsible for the finished products and the incoming parts control. This kind of checking system has only very low passive effect on the real quality of the product. Only separation of the bad and good quality raw materials, incoming parts and final products. This is not so much but a good starting point.

\subsection{Second period: $P Q C$}

In the second phase, the focus moved to strong production quality control (PQC).The focus is on the production process but this is not a quality step ahead just the small quality virus started to grow (blue circle on the Fig. 1) and infects the production area not just the in and out coming process are infected like at QC. From management point of view, this step means that the production will be responsible for the quality of its tasks. This is the start point where everybody starts to be responsible for the quality of his tasks (not only for quantity, deadline, costs etc.). This is the start of privatization of quality.

\subsection{Third period: $T Q C$}

In the third period the virus started to grow quickly. This period is the total quality control. The first seriously infected companies were in Japan and USA with two difference mutations. In Japan it was called TQC (Total quality control), in American it was QA (Quality Assurance), later came Europe with QSS (Qualitäts Sicherung System) and ISO 9000. These viruses covered the total company and finally the total quality surface. The quality surface got a small thickness (see thick quality surface on the Fig. 1) it turn into a slim (red, yellow, green on the Fig. 1) quality plate (TQM?) and this is the first time when the "T" (total) appears and this is the first time when new symptoms appears what have never seen before these are the audits and these are infected the products. The main focus moved on the product audits. Slowly the product audits changed to process audits because the process audits have bigger effects on the quality than the product audits and the process audits also includes the product audits as well. From management point 
of view, the privatization of quality is increasing. Not "only" Quality and Production departments are responsible for quality. Every departments are responsible for the quality like Logistics, Human Resource, Purchasing, Maintenance, Research and Development as well.

\subsection{Fourth period: TQM}

The real change is the TQM when effective quality virus infected quality conscious management fulfils the entire space around the quality surfaces. Quality plate of the third phase (TQC) started to grow, it became a cube, and this TQM cube is fulfilled with quality conscious management.

It means the TQM cube does not has to be fulfilled with quality it has to be fulfilled with management! This is the key point, when instead of managing the quality system the comprehensive total management environment (the full cube, the 3 dimensions) takes over the quality consciousness. It gives us the final answer for Kano's dilemma [2]: "Management of quality or quality of management?" The quality of management takes over the leading role from the quality management on the quality developmental way. This is the reason why the process audits are changed to a total complex system audits (finance, human resource, production, quality, etc.). TQM is the most serious period. In this stage all the members of the company are infected very often those companies which are connected with the infected company became also quality virus carriers. The management became total quality conscious management and this is the key point, when instead of managing the quality system the comprehensive total management environment takes over the quality consciousness.

If the TQM is symbolized with a cube, in that case in the TQM cube arrows show, the two dimensional changes (planar, spatial).

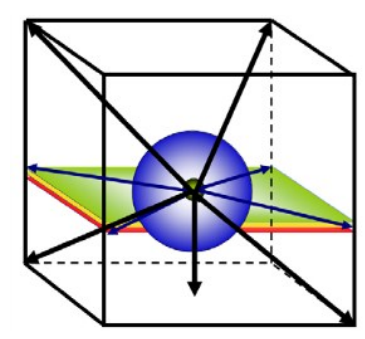

Figure 1. How the small quality virus infect the total organization [5]

The infected management areas are the follow:

Table 1. 12 elements of TQM [3]

\begin{tabular}{|l|l|}
\hline \multicolumn{2}{|c|}{ 12 elements of TQM: } \\
\hline Strategy management & Projekt and teamwork management \\
\hline Quality and reliability management & Accounting \& Finance management \\
\hline Human Resource management & IT management \\
\hline Design management & Management of quantitave methods \\
\hline \hline Marketing management & Production and technology management \\
\hline \hline $\begin{array}{ll}\text { General management culture, decision } \\
\text { system, leadership theory }\end{array}$ & Issue based problem solving \\
\hline
\end{tabular}

That accepted approach what say we have main and support process stronger and weaker departments has to be leaved. The SWOT analysis and the linked Pareto based development programs delivers low results from the whole company point of view- because the not A-category fields, departments will be never be developed. They remains weak. Better is to have a lower management levels across the organization than one extremely strong.

Therefore it is important the right distribution of resources among the different management fields. Focus cannot be only on the main productive systems, marketing and the other 11 elements (see Tab. 1.) have to 
be on the focus as well. Just on example: we could produce super high quality products with extremely low cost if nobody knows our product because the marketing budget is so low...

The decision of how to distribute the resources always has to be done in the given situation, in the given organization to get the most effective way to grow the organization. But for the right decision the managers has to know each other fields very well. For this skill they need interdisciplinary universal management knowledge. The entire system is no stronger than its weakest link!

But what quality virus infected companies are doing after the fourth TQM period? Why the quality management is still improving? Does fifth or even sixth period existing?

\subsection{Fifth period: New driving forces.}

In 2006, Feigenbaum explained the last 10-15 years tendencies on an international conference. The TQM is still improving and it is caused by six long evolution driving forces what are the follows:

- New effective approaches, methods and practices (QC, SPC, TQM, method systems) appears,

- Leading companies use these good practices, benchmarks are exists,

- Quality competition is globalized (and quickly change!),

- Customer satisfaction/dissatisfaction spread extremely quickly due to new possibility of information technologies,

- Organizations are continuously looking for new possibilities to increase the customer satisfaction (PDCA, CQI, CIP),

- Lead organizations keep the quality in the focus of their strategy.

\subsection{Sixth period: IMS}

Latest period could be the follows according to J. Topár [10]:

- The quality of management determines the success of the quality conscious company. But for this the quality management and its targets have to be integrated into the total organization so TQM conceptualization and practice focused management is needed.

- Integrated management systems (IMS) are needed where the essential management elements (sub systems - quality, health, security, environment, information, security systems, supplier, social responsibility etc.) of the company/organization/system have to be operated in one common integrated system.

- To increase the quality of management requires a comprehensive culture change in the company what reach all the level of management and every employee.

- Key factor of the operation is the continuous development. To measuring this the EFQM model [11] could be used what helps with a regular self-evaluation to systematically identify the strength and weakness of the organization and treat these points.

- Role of the third party certifications dynamically changed.

- Supplier, partner networks rethink is needed. Improvement and development processes have to be harmonized. Real information has to be shared.

- Sector specific quality systems and methods are used in service systems like public services: health care, administration, public education, public transport.

- The specific culture of the given organization have to be taken into consideration more significantly during the quality system and method selection process.

- Methods integrated into method systems (e.g. PDCA, DIMAIC, Six Sigma, Lean).

- Method systems converge to quality models and quality systems.

All in all the key points where methods and approaches have to be changed:

- Management areas connection,

- Management areas connection to quality management,

- Quality management connections with further quality functions,

- TQM and management and the quality management connections,

- Business excellence and well-operated quality system connections.

- Quality conscious managers, employees and owners are needed. 


\section{DEVELOMENT OF MANAGEMENT SYSTEMS AND THEIR CONNECTION TO QUALITY MANAGEMENT}

With a view of above trends, it was analysed from management science development point of view how the quality was integrated into the management systems and organization targets. This development presented on the follow "management by..." figure:

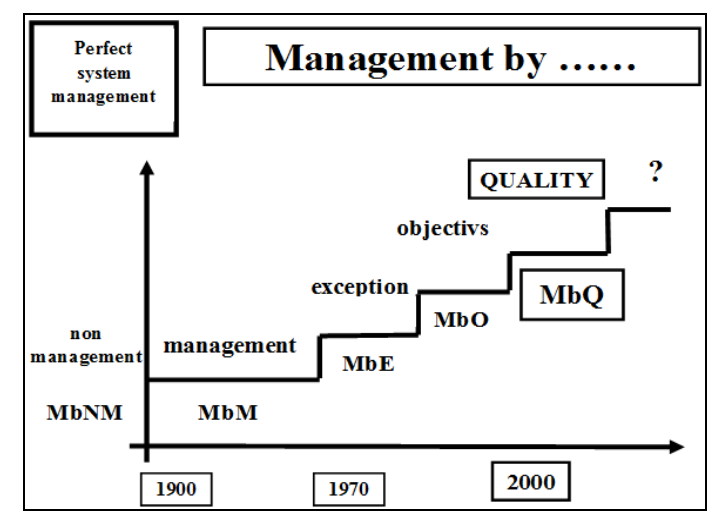

Figure 2. Management systems development till MbQ (=TQM?) [5]

To follow these periods, steps the organization could reach the TQM $=$ MbQ management level. The whole company could be infected if the organization put the quality into the main focus of the management so a quality committed management culture has to be implemented and operated. From this point of view in the main focus of the development has to be the management. It has to be developed to a quality conscious management. Among the organization targets have to be the quality (e.g. instead of current management by objectives or management by exception or just volume or profit oriented management).

So all in all the quality of the management has to be developed. In line with quality of management development process those management methods have to be used what could support the quality-focused targets (quality conscious culture spread could be led by strategy human resource and quality management). This methods could be the follows:

Table 2. Classical QM and new TQM methods [3]

\begin{tabular}{|c|c|}
\hline $\begin{array}{l}\text { Classical QM methods, } \\
\text { what partly used by TQM }\end{array}$ & $\begin{array}{c}\text { Comprehensive new } \\
\text { TQM methods }\end{array}$ \\
\hline $\begin{array}{l}\text { - Error analyze methods: } \\
\text { - Pareto/ABC, } \\
\text { - Ishikawa, } \\
\text { - FMEA/FMECA, } \\
\text { - TIPHIB, } \\
\text { - Problem solving methods, } \\
\text { - QFD/QH (quality house), } \\
\text { - Quality teams, } \\
\text { - List of open points, check lists, } \\
\text { - Quality audits, } \\
\text { - Statistical methods, } \\
\text { - Flowcharts, } \\
\text { - Statistical process control cards, } \\
\text { - } 5 \mathrm{~W}+1 \mathrm{H}, \\
\text { - } 5 \mathrm{~S}, \\
\text {-7 steps problem solving, } \\
\text { - 5M, } \\
\text { - Sampling methods. }\end{array}$ & $\begin{array}{l}\text { - Data collection, visualization, analyze, } \\
\text { - Benchmarking, } \\
\text { - SWOT analyze, } \\
\text { - Environment and market analyze, } \\
\text { - Portfolio analyze, } \\
\text { - Organization analyze, } \\
\text { - Mission, vision, } \\
\text { - Management style, } \\
\text { - Company culture and development, } \\
\text { - Communication analyze, } \\
\text { - Motivation analyze, } \\
\text { - Conflict and risk management, } \\
\text { - Environment protection and culture, } \\
\text { - Company audit, } \\
\text { - Human resource analyze and development, } \\
\text { - Work safety, health, work culture, } \\
\text { - JIT; TPM systems, } \\
\text { - PQC, SQM, } \\
\text { - 7M, 9M, } \\
\text { - PDCA problem solving, } \\
\text { - Method systems (PDCA, six-sigma, lean), } \\
\text { - QM method extension to non QM areas, } \\
\text { - Decision making process and delegation } \\
\text { analyze. }\end{array}$ \\
\hline
\end{tabular}


The effectiveness of the usage of certain methods significantly increases if these quality system methods are fitted to the organization specialties.

For example, it can be observed that each error analysis methods have been frequently used in combination, depends on their advantages and disadvantages. It is obvious for an Asian model using organization where lot of teams working continuously with lot of team members since several decades with significant quantities of good "quality" data and with strong IT background ([9] minimum of "how much?" but often "why?" type of data) the follow error analysis order would be good: 1. ABC Pareto analysis 2. For 'A' errors ISHIKAWA analysis, 3. for each of fishbone FMEA 4. for the most risky issues, a PDCA quality improvement projects with a narrower homogeneous team.

But for example, in the domestic practice where few teams working only with few team members and often the documentation is completely missing or the data and the IT support is on "when?" level [9] the follow error analysis order would be good for them: 1. brainstorm or TIPHIB (typical sources of error) analysis with large heterogeneous team 2. for the typical or highest risk errors ISHIKAWA or a Pareto data record 3. fix these critical issues with PDCA projects. My opinion is, in the domestic practice purpose to begin the analysis with more general methods (e.g.: strength-weakness analysis, SWOT, TIPHIB) or other soft, heuristic methods (e.g.: brainstorm addition to the foregoing, Kawakita, Jiro, $5 \mathrm{~W}+1 / 2 \mathrm{H}$ methods, $6.5 \mathrm{~S}$, PDCA).

\section{BUSINESS EXCELLENCE AND WELL-OPERATED QUALITY SYSTEM CONNECTION TO CULTURE}

\subsection{Seghezzi palace and American island}

The American island approach completely goes against the above written TQM and quality conscious management approaches, and it is accepted in the domestic practice as well, which does not place the focus on the development of the total management system, but out that where the whole organization is less sensitive to quality, higher success could be achieved, if an appropriate quality island, a department, expanding on the total company. - but the precondition of this is the quality of culture of society.

According to Seghezzi - European guru of quality management - the fundamentals of the quality palaces are the quality of the culture of the society. Only after a quality turn in the culture is realistic to reach success with a quality model in the practice especially if it is TQM based model.

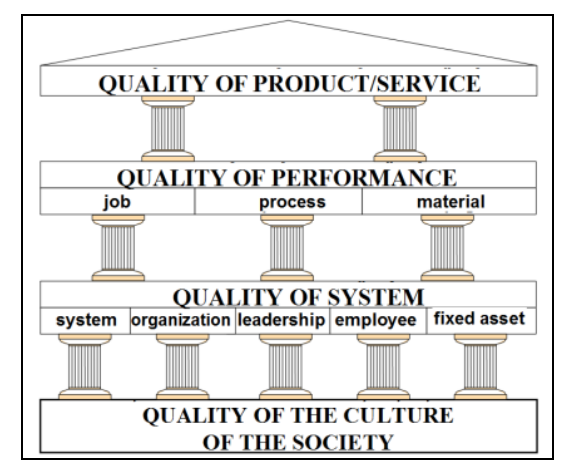

Figure 3. Seghezzi quality palace model [6]

Recent quality palaces are usually turned with $180^{\circ}$. The basic is the strict activities of the quality control what is focusing on the quality of the product/service. We can say that the basic of a comprehensive quality conscious development of the quality of management could be a turned pyramid, a turned palace. In the interest of a fully comprehensive quality turn of the management, the quality system itself has to be turned! According to my understanding, the comprehensive definition among the quality definitions is the quality management what includes all the quality activities. The hierarchic pyramid of these activities are the follow:

- Quality management,

- Total quality control,

- Quality assurance,

- Quality control. 
All in all according Seghezzi the companies have to support the development of the quality of culture of society to help to build up a stable quality palace.

\subsection{Instead of better management of quality, better quality of management}

The quality competition regions of the world (USA, EU, Japan and its followers) in the last 100 years are searching continuously the way to TQM but they are doing it on different ways. (These different approaches rooted on different society cultures and the discrepancies among these ways are likely caused by the (quality of) culture.) According to my opinion, it also means that instead of better quality management the focus has to be on better quality of management to find the way to TQM in the interest of successful competitive operation and excellent business performance.

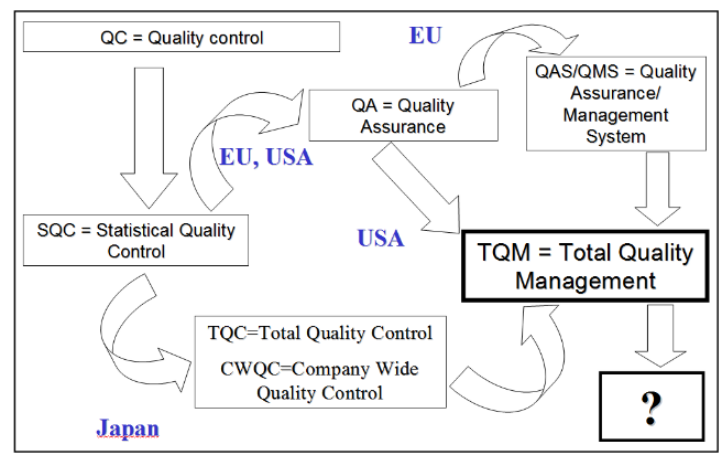

Figure 4. Way search of the quality systems to TQM in different regions [5]

The management always have to control that the organization is on the good way to TQM or not. For this the audits could provide a great overview about the organization.

\subsection{Audits with new approaches}

To increase the effectivity of the organization the roles of the audits should be increased. Especially the internal auditor should play a bigger role. They should give the primary sources of the continuous improvement and development what elevate the organization on "higher" level (see Fig. 5).

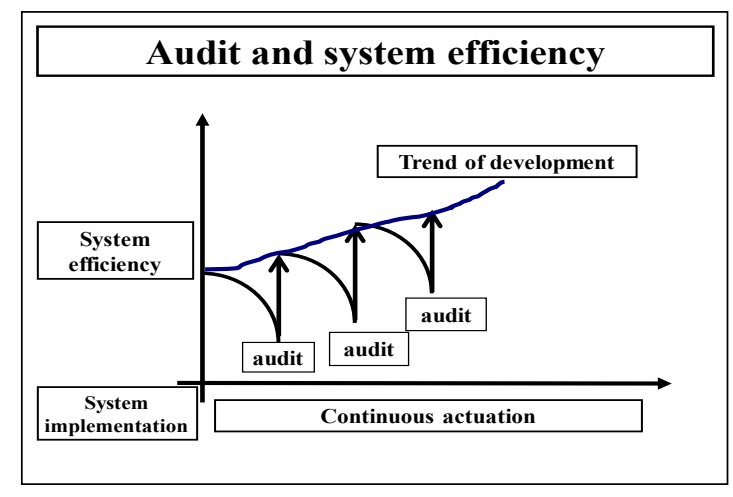

Figure 5. Audit and system efficiency [8]

However, for this the [8] internal audit should be understood and practiced on different way! First the audited and the auditor should have a common goal and it should be to increase the audited organization / system / business / enterprise competitiveness through continuous development and improvement.

Therefore, during the internal audit it is very important to identify the inappropriate processes and offer solutions for these issues and not just recording the actual appropriate well running processes. Viewed from this perspective the internal auditor's expertise and active role in proposing overwrite the independence criterion (but of course, during the third party audit the auditor has to be independent - it is a primary requirement.) So all in all do internal audits! - but on another way! 
On one side, the auditor(s) should propose solutions for the long-term development and improvement processes and offer solutions for the problem prevention processes as well. On the other side they should approach the audit process on different way. The audits could be done according to the eight principles of the MSZ EN ISO 9000: 2005 (or the focus could be put on some major elements.) In this case the audit has to be done according to the follow eight principles:

1. Customer focus organization and operation,

2. Leadership,

3. Involvement of people,

4. Process approach,

5. System approach management,

6. Continuous improvement,

7. Fact based decision-making,

8. Mutually beneficial supplier relationships.

The management (or the auditors) has to find which principles are weak in daily life of the organization and these has to be audited. For example, the ISO 9001:2008 principle of continuous improvement must be audited in connection with the following system elements:

4.1 General requirements,

5.1 Management commitment,

5.2 Customer focus,

5.3 Quality policy,

5.6 Management review,

6.1 Provision of resources,

8.5 Improvement,

8.5.1 Continuous improvement.

Let the organization check systematically: whether these principles are in the documentations and in what form or are they in the related working orders and if yes in that case how these operate in practice (of course in one system element more principles may appear, these could be audited according to more principles!).

TQM-like audits guiding principle can be the well-known three principles (customer focus, the (processes), continuous improvement and development, the full employee empowerment) and their supporting elements (education, training; communication; flexible supporting organization; motivation, recognition; evaluation, measurement, analysis). They must be connected together with certain elements of the system during an audit (e.g. the related elements of continuous improvement and development).

As it was demonstrated in a previous table, the thematic key elements of the TQM oriented, and therefore more stable and long-term focused, third dimension" quality conscious management environment is the 12 points of TQM (see Tab. 1).

To this American approach is close the German-based 5M, 7M, 9M perception what says: the key elements of a well-managed quality-conscious system are the follow:
1. Men
2. Management
3. Method
4. Material
5. Machine
6. Milieu
7. Motivation
8. Maintenance
9. Money.

Audits could be done based on these elements or again the weak points of the organization has to be determined and these points have to be audited.

The departments, the key elements, the principles has to be brought into line with the standards and the quality system of the audited organization and the audit has to be done according to this process. 


\section{HOW TO GO FURTHER? WHAT TRENDS SHOULD BE FOLLOWED AND HOW THE DOMESTIC QUALITY MODEL SHOULD LOOK LIKE?}

Globalization caused that neither the American nor Japanese nor European quality management systems could be applied alone. A mix of these quality systems have to be applied then it has to be operated and audited but how it should look like?

What could be the basic practice elements of the domestic quality model based on the above analysis? What key elements could be implemented from the 3 approaches (see Fig. 4) into the operations of domestic quality-conscious system and which systems could be best utilized to improve the domestic quality management systems?

1. Focus on the quality management and the quality control instead of the quality assurance and quality check. This requires that the whole system has to be in the focus of the operation not just the formal quality department and its employee. Everybody in the organization has to be responsible for the quality of its activities, and its continuous improvement-development.

It also requires that in mentality of the top management and practical activities the quality thinking / quality consciousness has to be appear and the quality has to part the daily activity of an adequate number of employee in all departments.

2. The system set up and establishment has to be very stable, massive. Significantly longer time needed to deepen the system operation and its continuous operation, improvement and development. In my opinion this requires more time than what is usually spent in domestic systems. In the domestic systems the Hungarian companies reach the ISO 9001 certification and its quality level within 1-1,5 years while in Europe it takes 2-3 years [4]. More efforts and attentions have to be paid on the daily continuous operation processes and quality system development process than just a few internal audit and one management review between two external audits. But for this the employees have to be involved and they have to be trained to quality, they have to get the quality virus and they have to spread it as well. More and more employee have to be involved not only the employee of the quality department.

3. In the total system about $10-25 \%$ of employees have to be trained with the right, organization fit quality methods and techniques (e.g. "four simple", "the four best" or "the seven best" methods) and involve them into continuous improvement and development processes (CIP, PDCA, CQI).

This development and implementation requires a full systematic education and training program. Its execution -and finally the way of thinking change- will take minimum 3 years but 5 years is more realistic.

4. Minimum have a top management team, all key process have to have an expert team and a quality specialist and a methodology specialist. These teams have to have a team leader who has the needed decision making rights. The team leader should have a professional and personal prestige as well and have access to the needed resources to implement quality activities.

5. On the focus of the ongoing internal quality improvement has to be the complex error analysis what has to be build up on reliable data and information base, and with its help continuously reduce the level of errors and improve the "quality performance". Regular data collection, analysis, continuous feedback and control, continuous team activities and regular management evaluation of these teams, team motivation are needed and of course, the setbacks, failures, nonconformities has to be regularly reported as well.

6. The aim of the operation has to be to reach the "zero-error" level what based on a "third generation" regulated system basis. This requires the knowledge of the current level of capability. The common continuous development goals have to be determined and the employees have to be motivated in line with the common goals.

7. The deliverer level should be the "second generation" middle professional management level.

The middle level managers should have the suitable position and/or the suitable professional prestige. They should manage the daily continuous development and improvement process and they should represent their quality commitment in the practice as well.

8. Establish American-minded "management climate." It means for the top management the management itself has to shows example of the high quality of its activities, commitment to quality and its practical implementation. Management has to provide the necessary work conditions and resources for quality work and motivate the employees, adhere to the quality requirements and require it from the suppliers and provide for the customers.

9. Operate and empower the teams on "Japanese" way, prepared them with the necessary knowledge and PDCA understanding but for this process first the management has to prepare all the conditions for the 
quality work than they could require the quality work from employees. Educations and trainings has utmost importance in this activity.

10. The final objective is try to reach a TQM-like operation. This requires that for the practical cases in the specific system adapt the principles of TQM. In my opinion it means that primarily the TQM basic principles of continuous improvement and development has to be established. More and more employees has to be involved in quality development processes (suggestions, ideas request; education training, contribution to team works. involvement into the goals set up, continuous presentation of quality system etc.).

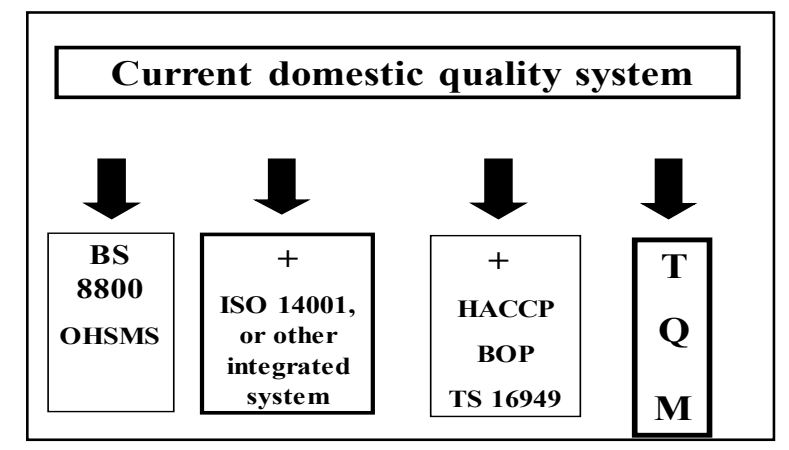

Figure 6. Possible development ways to the domestic quality model

Some other recommended weighted criteria resulting from the foregoing:

Table 3. Weighted order of TQM principles [4]

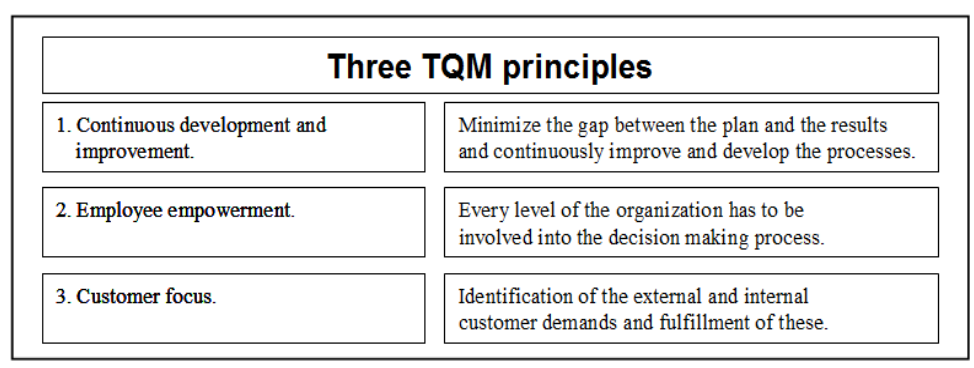

Table 4. Weighted order of ISO 9000 principles [4]

\begin{tabular}{|l|l|}
\hline \multicolumn{1}{|c|}{ Minimal required quality system } \\
\hline Fundamental objective & Required quality system \\
\hline Meet the specifications & Quality control \\
\hline Meet the function requirements & Statistical quality control \\
\hline Meet the evident customer demands & Total quality control \\
\hline Meet the hidden customer demands & TQM \\
\hline $\begin{array}{l}\text { Meet the environmental and society } \\
\text { demands }\end{array}$ & Integrated systems \\
\hline
\end{tabular}


Table 5. The connection of the quality system and fundamental objectives [4]

\begin{tabular}{|l|}
\hline \multicolumn{1}{|c|}{ Four from the eight principles of ISO $\mathbf{9 0 0 0 : 2 0 0 5}$} \\
\hline 1. Continuous development and improvement. \\
\hline 2. Leadership skill of management. \\
\hline 3. Employee empowerment. \\
\hline \hline 4. Customer focused organization and operation. \\
\hline
\end{tabular}

Today quality management is already able to provide help to the management to choose which quality system best fits to the organizational / corporate goals and in the same time it points out that what is the connection between the "total" management and the quality management all in all the quality management system has to fits to the organization goals.

\section{CONCLUSION}

Clear Japan, American, European solution is not exists. Due to the globalization mix quality systems are growing up. Basic elements (see Tab. 2) and quality systems (e.g. see Fig. 6) are existing but always the management has to decide which basic elements and how could support the spread of the quality virus to reach the best organization goals.

The quality virus is not a simple virus in the body of the organization. It is itself the life. According to Scheele, president of Ford Motor Company [1]: The perfect is already not enough. Those companies what are let the quality virus to spread everywhere in the organization and in its environment will be successful in long term the other uninfected companies will be out of the market soon.

The main reason of it is that all the customers are already infected with the quality virus and they are looking for products and services what are created only by VICs virus infected companies. The others in long term are definitely not welcome anymore.

\section{REFERENCES}

[1] Goetsch, D.L., Davis S. B. (2010) Quality Management for organizational excellence introduction to total quality, sixth edition, New Jersey.

[2] Kano, N. (2007): Evolution of quality - the way to sustainable growth. Minőség és Megbízhatóság, Budapest.

[3] Szabó, G. Cs. (2013): Usage of TQM (second edition). College note for commercial and marketing students in TQM specialization, Wekerle Business School, Budapest.

[4] Szabó, G. Cs. (2013): The domestic and international regulation of quality. College note for commercial and marketing students in TQM specialization, Wekerle Business School, Budapest.

[5] Szabó, K (2014): The guarantee of quality is the quality of management. ESD, Economic and Social Development 5th International Scientific Conference, Belgrad.

[6] Szabó, K-Szabó, G. Cs. (2013): 102 years of Taylor quality. Lecture on the 3rd management conference: "Management and organizations 102 years after Taylor", Szeged.

[7] Szabó, G. Cs.: (2012) From obstacle clearing till Doctoral School. The actual questions of industrial engineering. Budapest University of technology and Economics, Management and business economics professorship, Müszaki Publisher, Budapest.

[8] Szabó, G. Cs. (2014) Supplement with audit approaches for the quality management methods course for quality engineer and quality manager students, Budapest University of technology and Economics Engineering Training Institute, Budapest.

[9] Szabó, G. Cs. (2010): Peaceful coexistence of the managers and the risk, Harvard business review, Hungarian version 12. (Budapest)

[10] Topár, J. (2012): Quality management trends in production and service sectors. The actual questions 
of industrial engineering. Budapest University of technology and Economics, Management and business economics professorship, Müszaki Publisher, Budapest.

[11] www.efqm.org was available on the internet on 28.11.2014. 